\title{
Dekonstruksi Haji Dan Umrah Dalam Dakwah
}

\author{
Afif Via Syahdaniya ${ }^{1}$, Samsul Rifa' ${ }^{2}{ }^{2}$ \\ UIN Sayyid Ali Rahmatullah Tulungagung \\ viasyahdania@gmail.com
}

\begin{abstract}
The da'wah model that is increasingly dynamic is caused by the development of the times and technological advances. The development of the modern era which is actually experiencing a setback has become a phenomenon that is happening today. Changes in the process of Hajj and Umrah at this time need to be adjusted to the principles of Islamic da'wah fiqh in the teachings of Islam. The implementation of the Haij and Umrah pilgrimages, which should be easier by looking at the flashbacks of the Haij process in ancient times, is in fact currently experiencing a setback. with conditions that are not good or even bad. Haij and Umrah, which are supposed to be the most sacred journeys of worship to the Baitullah, are in fact currently happening many phenomena wrapped in a desire to fulfill emotional needs. This research was carried out using the library research method in several journals and books related to this discussion. This is discussed differently such as how the process of Haij and Umrah in ancient times underwent changes in today's modern times. Haij and Umrah are not ordinary journeys, but in them there is a journey of worship to fulfill the call of Allah SWT along with the spiritual and inner heart of a Muslim. So it is not appropriate if the pilgrimage and umrah are mixed with worldly affairs.
\end{abstract}

Keyword: da'wah, deconstruction of hajj.

Abstrak. Model dakwah yang kian dinamis disebabkan oleh seiring berkembangnya zaman dan kemajuan teknologi. Perkembangan zaman modern yang malah mengalami kemunduran menjadi suatu fenomena yang terjadi saat ini. Perubahan proses ibadah haji dan umroh saat ini perlu disesuaikan dengan kaidah-kaidah fiqih dakwah di dalam ajaran agama islam. Pelaksanaan ibadah haji dan umroh yang seharusnya lebih mudah dengan melihat kilas balik dari proses haji di zaman dahulu namun pada kenyataannya saat ini mengalami kemunduran dengan keadaan yang kurang baik bahkan buruk. Ibadah haji dan umrah yang semestinya menjadi perjalanan ibadah paling sakral menuju Baitullah faktanya saat ini banyak terjadi fenomena-fenomena berbalut hasrat untuk memenuhi kebutuhan emosional. Penelitian ini dilakukan dengan metode kepustakaan pada beberapa jurnal dan buku yang berkaitan dengan pembahasan ini. Ini dibahas dengan berbeda seperti bagaimana proses haji dan umrah pada zaman dahulu mengalami perubahan di zaman modern saat ini. Haji dan umrah bukanlah perjalanan biasa, tetapi di dalamnya terdapat perjalanan ibadah memenuhi panggilan Allah SWT beriringan dengan ruhani dan batin seorang muslim. Maka kurang tepat jika ibadah haji dan umrah dicampurkan dengan urusan duniawi.

Kata Kunci: dakwah, dekonstruksi haji. 


\section{PENDAHULUAN}

Dakwah Islam yang terus berkembang oleh banyaknya faktor perubahan sosial saat ini menuntut seorang muslim mengikuti perkembangannya dengan berbagai cara yang ada, demi tercapai tujuan dari pesan-pesan dakwah yang akan disampaikan. Salah satu faktor perubahan sosial pada masa ini yang sangat berpengaruh terhadap keberhasilan da'i adalah kemajuan dan perkembangan teknologi modern yang begitu pesat perkembangannya. Searah dengan yang dijelaskan oleh (M. Munir, 2006) “ Pengertian Dakwah adalah aktivitas mengajak, mendorong dan memberikan motivasi kepada umat manusia atas kemampuannya menuju jalan kepada Allah SWT dengan istiqomah serta berjuang bersama menjunjung tinggi agama Allah (Prenada Media, 2006: 18). Untuk mewujudkan kebaikan dalam beragama islam dan keselamatan dunia akhirat harus dilakukan dengan bersama-sama, bahwa dakwah dengan tujuan mewujudkan kebaikan sosial bukan hanya untuk mewujudkan kebaikan pribadi. Tujuan dari pesan dakwah yang disampaikan adalah untuk mendapatkan keselamatan di dunia dan akhirat. Dakwah terhadap yang telah dipraktekkan pun disebarkan melalui perkembangan teknologi saat ini tentu dengan sesuai kaidah-kaidah fiqih dakwah.

Kaidah-kaidah fiqih berdasarkan isi Al-Qur'an dan Hadist Rasulullah SAW adalah jawaban terhadap suatu permasalahan, yang semestinya digunakan untuk menjawab berbagai persoalan dakwah. Disampaikan oleh (Aziz, 2017) dalam bukunya ilmu dakwah bahwa terdapat dua bentuk kaidah yang dapat digunakan untuk melaksanakan dakwah. Pertama, kaidah fiqih adalah untuk dakwah (al-qawa'id al-fiqhiyyah li al da'wah) untuk menentukan hukum mengenai dakwah. Kedua, prinsip-prinsip dakwah (al qawa'id li da'wab) strategi atau metode untuk mencapai dakwah yang efektif (Kencana, 2017: 145). Era modern berhasil memunculkan da'i milenial untuk menjadi salah satu cara efektif dalam menyebarkan dakwah Islam saat ini. Menurut (Santoso, 2019) dalam tulisannya Revitalisasi Metode Dakwah Anakronitis Dai Generasi Milenial mengatakan bahwa faktor kemajuan teknologi modern memiliki dua nilai yang berbeda yaitu positif dan negatif. Positifnya pesan-pesan dakwah dengan mudah dan cepat diterima secara luas sedangkan negatifnya, pendakwah sebelum era milenial tergeser kedudukannya karena masih menggunakan metode sebelumnya (Tasamuh, 2019: 136). Positif dan negatifnya kemajuan teknologi saat ini tentu berpengaruh pada ibadah-ibadah yang memiliki nilai sakral namun berbalut hasrat dalam melaksanakannya. Salah satunya dalam 
ibadah haji dan umrah saat ini yang terus mengalami peningkatan dari jumlah pendaftar hingga peminatnya.

Arti prosesi ibadah haji adalah perjalanan ruhani seorang muslim menuju Allah SWT. Seorang muslim yang melakukan ibadah haji dan umrah memiliki sebutan sebagai tamu Allah yang hendaknya sebagai tamu memiliki etika dan menjaga adab batiniyahnya. Pada tulisan (Istianah, 2016) Rakhmat (1999) mengatakan bahwa Imam Ghazali menyebutkan etika dalam melaksanakan ibadah haji sebagai berikut: Menggunakan harta yang halal, tidak boros dalam membelanjakan hartanya untuk makanan dan minuman, meninggalkan segala akhlak buruk, memperbanyak berjalan, berpakaian dengan sederhana, bersabar ketika menerima musibah (Esoterik, Kudus: 34). Arti prosesi ibadah umrah sama dengan ibadah haji namun dalam pelaksanaannya memiliki perbedaan diantaranya pada ketentuannya, prosedur dan syarat-syarat pelaksanaannya yang tidak terdapat mabit di Mina, wukuf di Arafah dan melempar jumrah. Ibadah umrah dapat dilaksanakan kapan saja dan dapat dilaksanakan berkali-kali (Al-Amwal, 2019: 24).

Pelaksanaan ibadah haji memiliki berbagai resiko, seperti halnya resiko saat berada diperjalanan hingga resiko kematian faktor berdesak-desakan hingga terinjak-injak oleh sesama jama'ah saat melaksanakan rangkaian ibadah haji. Maka berbeda mengenai kewajiban syariat bahwa ibadah haji dapat dikatakan ibadah wajib terberat dalam agama islam karena berbagai resiko yang ada (Zainal, 2012). Tentu saja hal ini tidak dapat dijadikan alasan kuat untuk seorang muslim yang telah mampu tidak melaksanakannya. Bahwa segala takdir yang akan terjadi menjadi kehendak Allah SWT sedangkan manusia ditugaskan untuk memenuhi segala kewajiban sebagai seorang muslimin.

Ibadah haji dan umrah seharusnya menjadi seimbang antara kepentingan akhirat dan urusan dunia secara personal maupun sosialnya. Menjadi salah satu ibadah menuju taqwa dan iman kepada Allah SWT merupakan inti keagamaan sebagai urusan pribadi. Dijelaskan oleh (Madjid, 1997) pada buku Perjalanan Religius Umrah Dan Haji "Bahwa urusan pribadi hanya separuh benar karena urusan pribadi tidak dapat dimasuki oleh kepentingan orang lain namun ketika setiap individu melakukan amal saleh adalah bagian dari aspek consequential dari iman, sehingga mudah mudah memasuki kawasan sosial."(Paramadina, 1997: 87) ". Faktanya sebab faktor kemajuan teknologi dan berkembang pesatnya sosial media digunakan sebagai media menyebarkan segala sesuatu berita baik pada sebuah tulisan sampai pada gambar sebagai dokumentasi ibadah yang diberi tulisan atau biasa disebut 
caption. Seolah-olah menceritakan segala peristiwa yang telah dilalui dengan keadaan hati menginginkan orang lain dapat mengetahuinya, dengan niat menebar kebaikan ataupun yang lainnya. Hal ini merupakan tindakan urusan pribadi yang masuk ke dalam wilayah sosial.

Berbeda dengan fenomena yang saat ini terjadi terdapat juga permasalahan dalam pelaksanaan ibadah haji yang tidak dapat dihindari kaum muslim, di antaranya: pendaftaran haji melalui perbankan yang tidak dapat dihindari karena terdapat unsur riba didalamnya. Memungkinkan seorang muslim untuk Intiqolul Madzhab (bahwa muslim di Indonesia mayoritas menggunakan Madzhab Syafi'iyyah yang mana saat terjadi bersentuhan kulit antara lawan jenis dapat membatalkan wudhu, sedangkan saat pelaksanaan ibadah banyak berbagai umat muslim dari Negara di dunia juga sedang melaksanakan jadi sedikit kemungkinan untuk tidak terjadi sentuhan dengan lawan jenis, maka langkah yang digunakan adalah Intiqolul Madzhab. Penundaan masa haid seorang wanita dengan meminum obat sebagai pengatur siklus haid guna dapat melaksanakan ibadah dalam keadaan selalu suci. Selanjutnya permasalahan miqat yang memiliki 2 macam diantaranya : Miqat Zamaniyah (bulan Syawnal, Drulqo'dah dan Drulhijab) dan Miqat Makaniyah, tempat mula berihram bagi yang memiliki niat haji maupun umrah yaitu Dzulbualifah (Bir A'li) miqot penduduk Madinah, Al Jubfah (miqat penduduk Syam), Qornul Manazil (As Sailul Kabiir), Yalamlam (As Sa'diyah) miqot penduduk Yaman, Dzat Irqin (Adh Dhoribah) miqat penduduk Irak (Idawati, 2017).

Berkaitan dengan hal ini akan dibahas lebih mendalam terhadap fenomena-fenomena perubahan yang membangun tetapi malah mengalami kemunduran bahkan bisa dikatakan lebih buruk mulai dari proses pendaftaran hingga proses saat ibadah haji dan umrah berlangsung. Rumusan masalah terkait inti dari pembahasan tulisan ini diantaranya : bagaimana pengaruh dakwah diera digital?, seperti apa sejarah haji dan umrah d Indonesia?, apa saja syarat dan rukun-rukun ibadah haji umrah bahwa pembahasan diatas dapat menghasilkan gagasan baru berjudul Dekonstruksi Haji Dan Umrah Dalam Dakwah untuk dapat dipelajari maupun digunakan sebagai bahan evaluasi.

Tulisan ini disusun dengan metode library research yang bersumber pada jurnal-jurnal kemudian buku-buku tokoh ahli di bidang dakwah dan haji umrah. Penelitian ini dilakukan berdasarkan fenomena-fenomena yang terjadi saat ini seiring berkembangnya teknologi dan sosial media terhadap proses ibadah haji umrah. Analisis yang akan dibahas upaya penelitian dan analisis 
terhadap fenomena sosial saat ini di dalam lingkup dakwah. Data dalam tulisan ini didapatkan dengan cara memanfaatkan jurnal, buku dan sosial media sebagai bahan mendapatkan berita fenomena sosial yang sedang terjadi.

Melihat pada lingkungan sekitar pun penelitian terhadap sosial media yang menjadi bagian terpenting untuk mendapatkan informasi dan juga membagikan informasi. Awalnya sosial media digunakan sebagai alat komunikasi dan mencari informasi, kini telah bertambah fungsi untuk membagikan informasi yang bersifat pribadi maupun umum. Atas sumber jurnal, buku, berita mengenai ibadah haji umrah dan perubahan sosial dapat menghasilkan tulisan membahas perubahan yang terjadi pada proses ibadah haji umrah saat ini. Perlu adanya pembahasan lebih mengenai ibadah haji umrah yang telah terpengaruhi perubahan zaman dan perkembangan teknologi ini.

\section{HASIL DAN PEMBAHASAN}

\section{Dakwah Di Era Digital}

Segala aspek kehidupan pun aspek kehidupan beragama telah dipengaruhi oleh perkembangan teknologi yang semakin canggih dan dapat digunakan dengan mudah. Tentu banyak perubahan-perubahan yang terjadi dalam berkehidupan sosial. Perubahan-perubahan itu ada karena berbagai faktor yang mempengaruhinya. Perubahan sosial merupakan perubahan dalam segi struktur dan hubungan sosial yang berjalan dengan hukumnya sendiri tanpa ada kemampuan manusia untuk ikut terlibat didalamnya. Perkembangan zaman dan perubahan sosial saat ini mempengaruhi di kehidupan setiap masyarakat secara luas. Kebutuhan-kebutuhan dalam kehidupannya yang juga mengikuti perkembangan menjadi salah satu faktor manusia untuk dapat memenuhinya untuk kepentingan kebutuhan emosional ataupun finansialnya. Perkembangan zaman mengarah kepada perkembangan teknologi yang melahirkan sosial media atau sering disebut dengan dunia maya (Sulthon, 2003).

Fungsi teknologi informasi dunia maya ialah keterlibatan orang lain dalam proses berkomunikasi secara langsung. Jadi gaya komunikasi yang dibuat oleh dunia maya yaitu berkomunikasi yang melibatkan banyak orang di dalam proses interaksinya dari jarak jauh maupun dekat melalui alat komunikasi teknologi informasi yang ada. Jika dianalogikan, komunikasi sebagai objek dan dunia maya menjadi tempat atau media yang digunakan. Dengan Hal ini dapat menjadi satu kesatuan cara yang tepat dalam menyebarkan dakwah melalui teknologi informasi (Yedi Purwanto, 2017) . 
Hal ini juga menjadi tantangan dalam lingkup dakwah. Dampak dari perkembangan teknologi dan sosial media jadi dapat dengan mudah tersebarnya informasi, berita bahkan ilmu dari yang shahih dan palsu terutama pada pesan-pesan dakwah. Efek dari perkembangan teknologi media sosial bagi penyebaran pesan dakwah, contohnya dapat dilihat pada beberapa aplikasi pada handphone (hp) android digunakan sebagai media beribadah misalnya aplikasi Al-Qur'an, pengingat adzan, dan aplikasi lainnya berkaitan tentang ajaran agama islam. Adanya aplikasi tersebut mempermudah umat muslim untuk senantiasa lebih dekat kepada Allah SWT. Berdasarkan sabda Rasulullah SAW, "Sampaikanlah dariku walaupun hanya satu ayat" (Al-Bukhori, 2002). Allah SWT memerintahkan untuk menyampaikan kepada sekalian manusia, perintah untuk berinteraksi melalui komunikasi. Al-Qur'an merupakan sumber berita tentang agama islam dari Allah SWT untuk umatnya. Demikian pula sabda Rasulullah SAW yang memerintahkan untuk menyampaikan sesuatu yang berasal darinya, walaupun hanya satu ayat kepada orang lain. Hal ini menunjukkan bahwa Rasulullah SAW memerintahkan untuk menyebarkan informasi yang berasal dari beliau.

Pada setiap diri umat muslim dengan berbagai latar belakang kehidupannya memiliki kewajiban untuk berdakwah, karena dakwah dapat dilakukan dengan berbagai cara, tidak selalu menggunakan lisan dan tulisan saja. Dengan melakukan tindakan sosial secara langsung yang bermanfaat untuk orang lain juga merupakan cara berdakwah yang multidimensi. Seorang pendakwah yang baik, ustadz bahkan ulama' haruslah menguasai materi dan juga dapat memahami kebiasaan pun kondisi masyarakat sebagai mad'u (sasaran dakwah). Menggunakan bahasa yang baik dan cara yang tepat sesuai kondisi masyarakat saat ini tentu menjadi salah satu cara yang efektif dan mudah dimengerti dalam penyampaian pesan dakwah.

Umat islam harus menjadikan berdakwah suatu kebiasaan dan keharusan sebagai wujud menyampaikan kebaikan dan tanggung jawab moral terhadap sesama umat muslim. Berbagai strategi dakwah yang telah dilakukan supaya dakwah tetap berjalan seiring berjalannya waktu dan perkembangan zaman saat ini, menjadi bentuk perubahan dakwah ratusan tahun sejak dakwah secara lisan yang dilakukan Rasulullah sampai dengan dakwah saat ini yang memanfaatkan perkembangan teknologi dengan media-media yang ada. Maka perlu adanya generasi milenial memanfaatkan teknologi digital dengan mediamedia yang mempermudah dalam menyampaikan pesan dakwah kepada umat muslim secara luas. 


\section{Sejarah Haji Dan Umrah Di Indonesia}

Sekilas pengertian dan sejarah awal mengenai ibadah dan umrah berdasarkan sumber jurnal Muhammad Nuri dan buku Quraish Shihab dituliskan sebagai berikut : berada pada kitab "Fiqh Al-Hajj" disampaikan arti dari haji secara bahasa yaitu Al-Qasd artinya berhajat dan berkehendak. Secara istilah arti haji adalah berhajat mengunjungi Baitullah al-Haram untuk mengerjakan ibadah sebagai kewajiban dalam rukun islam ke 5 terhadap perintah Allah. Imam Ibnu Qudamah menyatakan makna haji adalah melakukan perjalanan menuju Baitullah (rumah Allah) dengan niat menunaikan ibadah sesuai dengan ketentuan syariat agama islam. Ibadah Haji merupakan ibadah yang wajib dilaksanakan setiap umat muslim sesuai rukun Islam dengan melaksanakan beberapa amalan tertentu seperti yaitu wuquf di Arafah, thawaf, sa'i dengan syarat tertentu (Nuri, 2014).

Haji adalah panggilan Allah maka dari itu jamaah haji dinamakan Dhuyuf Ar-Rahman (tamu-tamu Allah yang maha pengasih) bukan karena hanya berkunjung ke baitullab (rumah Allah) ? Rasulullah SAW bersabda : "(perlakuan) aku sesuai dengan hamba-hamba ku. Aku bersamanya apabila dia menyebut namaku, bila dia menyebutku dalam batinya, aku menyebutnya dalam diriku, bila dia menyebutku di hadapan kbalayak, aku menyebutnya di hadapan khalayak yang lebih baik dari khalayak itu. Bila ia mendekat padaku sejengkal, aku mendekat kepadanya sehasta. Bila dia mendekat padaku sehasta, aku mendekat padanya sedepa: bila dia datang kepadaku dengan berjalan perlahan, aku berjalan kepadanya dengan cepat (berlari) "( HR. Bukhari dan juga Muslim at-Tirmidzi dan Ibnu Majah). Hadist tersebut menunjukkan bahwa Allah SWT sungguh senang menyambut kehadiran hambanya, menjawab ketidak benaran atas kekhawatiran masyarakat bahwa Allah akan SW'T akan memperlakukan setiap hambanya yang berdosa sesuai dengan dosa dan pelanggaran yang pernah dilakukan. Bahwa siapapun yang datang kepadanya dengan tulus dan ikhlas pasti disambut dan dianugerahi serta dilimpahi karunia oleh Allah SW'T (Shihab, Haji dan Umrah Bersama Quraish Shihab, 2012).

Dituliskan oleh (Nuri, 2014) awalnya Umat Islam Nusantara di abad ke 16 memiliki keinginan kuat untuk melaksanakan ibadah haji melalui proses berdagang yang rumit dan banyak rintangan pada masa itu. Memasuki abad ke 17, seiring berjalannya kegiatan berdagang yang dijadikan peluang dan memotivasi masyarakat muslim indonesia dengan kuat untuk melaksanakannya kembali. Di abad 18 bukan lagi dengan alasan menggunakan jalur berdagang melainkan dengan alasan menuntut ilmu di negeri Arab. Salah satu rintangan 
saat itu adalah larangan ketat penguasa untuk menunaikan ibadah haji. Untuk dapat menghadapi rintangan pada waktu itu kaum muslim indonesia melaksanakan ibadah haji dengan cara lain beralasan untuk berdagang dan menuntut ilmu. Kemudian pada abad 18 dan 19 umat muslim terang-terangan dalam menyampaikan niatnya untuk berhaji di awal. Tidak lagi menggunakan alasan untuk berdagang maupun menuntut ilmu (Salam, 2014: 149).

Dari tahun ke tahun saat pelaksanaan ibadah haji di Nusantara mengalami perkembangan dan perubahan yang lebih baik. Awalnya hanya dengan memanfaatkan pengangkutan kapal laut Belanda yang kebetulan singgah di kepulauan Indonesia. Hingga akhirnya terdapat pribumi yang mampu memiliki kapal pribadi, milik salah seorang saudagar kaya yang berasal dari Makassar yang mengangkut para jamaah haji saat itu masih sangat sedikit, dengan biaya tertentu. ketika setibanya di negeri Hijaz dengan pelayanan yang sangat minimum, baik dari segi pengangkutan, penginapan, bimbingan dan sebagainya semuanya serba sederhana. Oleh karena susahnya mendapatkan kemudahan terutama dari segi kepengurusan, hingga akhirnya beberapa para jamaah dalam jumlah yang banyak memilih untuk menetap di dua negara suci Makkah dan Madinah. Namun diantaranya ada juga yang tinggal sementara untuk menuntut ilmu dan berdagang.

Kerajaan Arab memulai untuk membangun sarana dan prasarana pelaksanaan ibadah haji mulai dari asrama haji di semua Negeri dan Embarkasi melalui bantuan dana pendapatan kerajaan, kemudian menambah jumlah embarkasi tempat keberangkatan jamaah ke Arab Saudi, serta berbagai kemudahan lainnya untuk mendukung kegiatan operasional penyelenggaraan haji.upaya kerajaan Arab juga penyempurnaan sistem pelayanan seperti halnya penyempurnaan kepengurusan pembinaan petugas haji, pembuatan garis panduan berupa petunjuk pelaksanaan dan petunjuk teknis di setiap sudut layanan operasi penyelenggara haji. Untuk mendapatkan kajian lebih mendalam mengenai sejarah awal haji dan umrah di negara indonesia didalam jurnal karya Muhammad Nuri yang berjudul Pragmatisme Penyelenggaraan Ibadah Haji Di Indonesia.

\section{Syarat, Rukun-Rukun Dan Cara Pelaksanaan Ibadah Haji Umrah}

Disampaikan pada buku Quraish Shihab, syarat wajib haji yang paling utama adalah mempersiapkan diri, mental,spiritual, ilmu, materi, jasmani dan rohani sebaik mungkin untuk dapat melaksanakan ibadah dengan sempurna juga aman atas dirinya pun orang sekitarnya. Pertama, seorang muslim hendak melaksanakan ibadah haji dan umrah adalah beragama islam, seorang mukallaf 
berniat dengan sungguh-sungguh bermaksud menyerahkan dirinya, membersihkan dirinya, bertaubat kepada Allah SWT (Shihab, 2012). Mempersiapkan kesiapan diri secara mental disertai niat yang baik dan sungguh-sungguh menjadi hal utama untuk dapat menjalankan ibadah haji umrah dengan lancar menuju ridho Allah SWT. Kedua, berakal sehat untuk dapat mengerti dan memahami setiap dari tata cara dan tujuan ibadah yang akan dilakukan secara sadar. Ketiga, merdeka dan lepas dari ikatan perbudakan, telah mampu untuk beribadah dan berserah diri sepenuhnya pada Allah SW. Keempat, mampu secara mental, fisik dan material. Memiliki fisik yang sehat dan tidak sedang sakit tidak ada paksaan untuk tetap melaksanakan ibadah ini meskipun terdapat kemampuan dari segi hal lain. Kemudian mampu secara rohani memastikan mental sebagai bekal berupa ilmu pengetahuan, kesabaran dan ketaqwaan serta material yang cukup bukan hanya saat keberangkatan tetapi juga saat keberangkatan tetapi juga saat berlangsungnya ibadah disana sampai juga kepada kemampuan material terhadap keluarga yang ditinggalkan. Kelima, segera melaksanakan dan tidak menundanya kecuali sedang dalam keadaan yang mendesak untuk menunda waktu pemberangkatan hingga waktu yang dianggap telah tepat dan sesuai. Keenam, adanya mahram bagi seorang perempuan untuk mendampingi selama perjalanan tersebut.

Selanjutnya rukun-rukun ibadah haji yang harus dikerjakan sesuai dengan ketentuan dalam ajaran agama islam. Rukun haji oleh Mazhab Imam Syafi'i yaitu : Pertama, Ihram (niat saat akan mulai melakukan kegiatan haji ataupun umrah di waktu dan tempat tertentu). Kedua, Wukuf di arafah (dilaksanakan di waktu dzuhur tanggal 9 dzulhijjah hingga munculnya fajar di hari berikutnya). Ketiga, Thawaf al-ifadhah (mengelilingi ka'bah sebanyak tujuh kali putaran, yang dilaksanakan di dalam masjidil haram dengan menutup aurat dan syarat-syarat lainnya). Keempat, Sa'I di antara shafa dan marwah (kegiatan perjalanan mulai dari shafa ke marwah satu kali kemudian kembali dari marwah ke shafa satu kali dan diulang sebanyak tujuh kali). Kelima, Mencukur rambut kepala (sebagai tanda tahallul minimal tiga helai rambut sebatas ujung jari dan diperuntukkan kepada pria maupun wanita). Keenam, Tertib atau berarturan (Shihab, 2012)

Cara pelaksanaan ibadah haji dan umrah terdapat tiga cara, yang pertama melaksanakan umrah terlebih dahulu disaat akan melaksanakan ibadah haji yang disebut sebagai haji tamattu'. Kemudian yang kedua haji ifrad, melaksanakan haji saja tanpa umrah, namun jika berkeinginan untuk melaksanakan umrah maka ibadah umrah baik wajib ataupun sunnah 
dilaksanakan setelah ibadah haji selesai. Ketiga, haji qiran yaitu menjadikan satu niat secara bersamaan saat melaksanakan ibadah haji dan umrah. Syarat, rukunrukun dan cara pelaksanaan ibadah haji dan umrah perlu dipelajari lebih mendalam melalui buku-buku, kitab atupun media lainnya yang lebih mendalam pembahasannya guna memperkuat pengetahuan sebagai bekal di hari ini maupun nanti dalam menghadapi perkembangan era. Karena penting untuk mendapatkan ilmu atau informasi yang benar dan sebagaimana mestinya supaya tidak mudah menerima segala ilmu baru dari sumber yang kurang jelas sanadnya sebab mudah tersebarnya oleh sosial media yang berkembang saat ini.

\section{Dekonstruksi Haji Dan Umroh}

Berdasarkan beberapa pembahasan diatas adalah untuk menyelaraskan terhadap perubahan-perubahan dan fenomena-fenomena yang terjadi saat ini terhadap ibadah haji dan umrah. Pertama, Faktor dari perkembangan zaman dan perkembangan teknologi yang telah mempengaruhi atas perubahan proses pemberangkatan ibadah haji di negara Indonesia ini. Kapal belanda yang sedang berlabuh di kepulauan indonesia dimanfaatkan sebagai transportasi keberangkatan ibadah haji di abad ke 16 atas perubahan yang terjadi pada situasi dan kondisi. Awal tahun 1990 kuota pendaftar telah dibatasi karena jumlah pendaftar yang mencapai 200 ribu an. Atas dasar hal tersebut Kerajaan Arab Saudi menggunakan sistem Teknologi Informasi (IT) untuk mengatur proses penyelenggaraan ibadah haji mulai dari sistem pendaftaran, pembayaran $\mathrm{BPIH}$, proses administrasi dan penyelesaian dokumen, serta pelayanan operasional pengelompokan jamaah dalam kloter saat terbang ke Arab Saudi.

Pembaharuan dengan menggunakan sistem teknologi informasi yang digunakan dalam pelayanan sangat bermanfaat dan memudahkan terutama pada sistem pelayanan penerbangan internasional. Hingga ditemukannya model pendaftaran haji lima tahun yaitu sistem pembayaran langsung lunas dan sistem tabungan dengan sistem satu atap atau (First Input First Out FIFO). Hal ini merupakan wujud langkah menunjukkan kepastian pemberangkatan dan percepatan dalam pelayanan kepada seluruh jamaah haji. Perkembangan sosial dan kemajuan teknologi berdampak pada penyelenggaraan ibadah haji, yang seharusnya berfokus pada permasalahan ibadah justru berkembang kepada masalah lain diantaranya ; bisnis, sosial, budaya, bahkan politik. 
Tentu perubahan-perubahan mulai dari sistem, pendaftaran dan pemberangkatan yang memanfaatkan teknologi informasi pada saat itu hingga saat ini sangat efektif, menjadikannya semakin berkembang dan termanajemen dengan baik. Seiring berjalannya tahun ke tahun kuota pendaftar di negara Indonesia dengan masyarakat penganut agama islam terbanyak di dunia terus bertambah dan terus mendapat kuota tambahan dari kerajaan arab saudi. Dari awalnya menggunakan sistem FIFO dengan masa tunggu keberangkatan waktu 5 tahun sekarang menurut data yang diperoleh dari web resmi kemenag negara indonesia bahwa masa tunggu keberangkatan paling cepat adalah 12 tahun sedangkan yang paling lama 46 tahun (Kemenag, 2021). Karena setiap wilayah atau kabupaten berbeda masa tunggu karena jumlah pendaftar di setiap kabupaten yang berbeda.

Fenomena selanjutnya adalah seharusnya teknologi android dan media sosial difungsikan untuk media berkomunikasi, berkoordinasi dan buku panduan online ketika menjalankan ibadah haji umrah namun pada kenyataannya saat berada disana alat komunikasi berupa handphone android yang malah memiliki fungsi lain digunakan untuk mengabadikan setiap moment dengan memfoto, memvideo bahkan selfie di depan ka'bah beserta sekitarnya. Fenomena ini sering dijumpai pada sosial media umat muslim yang membagikan foto maupun video saat melakukan ibadah haji umrah di makkah dan Madinah. Jika zaman dahulu berfoto di sekitar ka'bah atau sekitarnya sebagai koleksi pribadi yang dicetak dijadikan kenang-kenang an maka saat ini seiring berkembangnya teknologi yang memudahkan pengguna untuk melakukan apa saja yang diinginkan seperti dengan Foto maupun video kemudian dibagikan melalui sosial media seperti whatsapp, facebook, instagram dan lainnya dengan menyertakan berbagai macam tulisan atau biasa disebut dengan caption yang menarik, caption mengenai dakwah bahkan sampai ke menceritakan atau berbagi pengalaman pribadinya saat berada disana. Hal ini berdasarkan pengamatan penulis dalam penggunaan sosial media di era digital yang menemui dekonstruksi hal ini.

Disampaikan pada buku (Madjid, Perjalanan Religius Umrah dan Haji, (1997) menunjukkan bahwa perubahan sosial benar-benar telah mempengaruhi segala aspek dan kehidupan masyarakat secara luas. Padahal inti dari keagamaan sebenarnya terletak pada urusan pribadi terhadap personal experiences (pengalaman pribadi) yang sangat mendalam, bukan lagi masuk pada keilmuan psikologi namun sudah masuk pada urusan spiritual pribadi yang 
didalam agama islam diharapkan sampai diharuskan untuk menjadi suatu komitmen sosial (Paramadina, 1997: 88).

Kemudian (Syari'ati, 2003) mengatakan, Sesungguhnya saat menjalankan thawaf, manusia tidak bisa memasuki atau hanya diam saat di ka'bah. Manusia harus merasakan jatuh dan menghilang di tengah pusaran keramaian manusia. Ikut larut dan hanyut di antara keramaian umat manusia yang menggelora sampai gelapnya hari saat mengelilingi ka'bah. Dengan maksud segerombolan orang yang menjadi tamu di Baitullah menggunakan pakaian dengan bentuk dan warna yang serupa serta diantaranya tidak ada perbedaan maupun kelebihan terhadap setiap pribadi (Jalasutra, 2003: 58).

Dari pernyataan dua tokoh diatas cukup menguatkan makna dari ibadah haji dan umrah yang seharusnya menjadi ibadah sakral, tidak seharusnya mencampurkan urusan ibadah dengan urusan dunia karena dapat mengganggu kekhusyukan saat beribadah dan jika tidak berhati-hati dalam menata niat serta tujuan maka jauhlah dari kata mabrur tujuan dari ibadah haji umrah yang seharusnya. Maka perlu adanya kesadaran untuk dapat memahami makna dari ibadah haji dan umrah yang akan dilaksanakan, bahwa unsur terpenting bukan hanya soal kemampuan secara fisik, mental dan juga material namun juga kemampuan dalam memahami arti, makna ibadah haji yang sesungguhnya kemudian tidak mencampurkan urusan ibadah dengan urusan dunia. Hal ini termasuk perubahan baru yang membangun namun pada kenyataanya mengalami kemunduran dengan kondisi yang lebih buruk.

Komodifikasi umroh sebagai life style atau Gaya hidup dan sarana rekreasi masyarakat berbeda dengan kelompok orang-orang mampu secara materi, orang-orang kelas menengah, selebriti dan mereka yang sukses karena masalah gaya hidup yang tidak sesederhana gambaran kehidupan mereka. Terdapat juga dalam jumlah banyak ditemui orang-orang yang kurang mampu secara materi mengikuti gaya hidup tertentu. Kebiasaan bergaya tidak selalu karena uang dan perilaku dalam mengonsumsi namun lebih pada pilihan dalam menentukan gaya. Mengenai selera dan gaya hidup tidak ada lagi batasan kelas sosial, melainkan telah menjadi lintas kelas dalam struktur masyarakat. Telah jelas disebutkan dalam keadaan mampu secara fisik, mental dan juga material yang cukup tidak hanya saat pemberangkatan tetapi juga saat sedang berada disana sampai dengan kecukupan material terhadap keluarga yang ditinggalkan.

Dick Habdige (1979) pada jurnal (Sucipto, 2013) menjelaskan Lima bentuk Gaya (style) diantaranya : Gaya (Style) sebagai komunikasi yang dimaksud untuk mendapatkan perhatian pada dirinya sendiri, sehingga 
dirinya memiliki eksistensi, Gaya sebagai Bricolage penciptaan terhadap sesuatu atau sebuah karya hal yang terjadi pada prosesnya, Gaya pada putaran gaya, Gaya sebagai homologi yaitu kesamaan asal-usul yang menunjukkan adanya hubungan kekerabatan sekalipun bentuk, susunan, atau fungsinya mungkin berlainan, Gaya sebagai praktek penandaan Gaya hidup bisa dilihat dari cara berpakaian, bahasa, kebiasaan, dan lain-lain (Kontekstualita, 2013: 26 ).

Pencantuman gelar haji dan hajah kepada jamaah yang telah selesai dan sampai ke tanah air merupakan suatu gelar bentuk kehormatan yang sudah ada sejak awal-awal proses ibadah haji umroh terlaksana di negara indonesia. Tentu hal ini tidak memiliki dalil ataupun dasar kuat didalam ajaran agama islam, melainkan hanya budaya turun temurun yang masih digunakan. Tidak dapat dikatakan sesuatu yang buruk maupun salah dalam hal ini selama dalam niat yang benar dan tidak menyalahi hukum dalam beragama islam. Namun kenyataannya pada saat ini karena faktor dari perkembangan teknologi dengan munculnya sosial media gelar haji hajah tidak hanya sebatas gelar yang disebut dengan ucapan melainkan juga berupa tulisan gelar yang dipajang secara cetak atau hanya untuk bahan eksistensi dalam bersosial media. Tentu ini merupakan bagian dari dekonstruksi ibadah haji dan umroh (Admin Sumbar, 2021).

Didalam pengalaman pribadi kerap kali menemui hal-hal yang diistilahkan sebagai the meaning of life, the purpose of life dan permasalahan ketenangan batin lainnya. Jadi memang benar bahwa semua pengalaman pribadi bersifat otentik terhadap orang tersebut. Artinya bahwa setiap individu dapat mengambil pelajaran dan kesimpulan dari pengalaman pribadi orang lain, dan setiap individu tidak dapat meminta atau membagikannya guna mendapatkan pengalaman tersebut. Dapat disimpulkan bahwa gelar haji dan hajah adalah bentuk penghargaan atas pengalaman perjalanan menuju Baitullah melalui proses yang agak rumit dan biaya yang lumayan besar (Madjid, Perjalanan Religius Umrah dan Haji, 1997).

\section{PENUTUP}

Dekonstruksi ibadah haji dan umrah merupakan perubahan yang membangun tetapi malah mengalami kemunduran bahkan bisa dikatakan lebih buruk keadaannya terhadap pelaksanaannya. Perkembangan teknologi ini yang melahirkan sosial media benar-benar mempengaruhi perubahan 
secara internal maupun eksternal. Secara sadar pun tidak sadar nilai sakral dan spiritual seorang muslim dalam melaksanakan ibadah haji umrah tercampur dengan urusan dunia berupa eksistensi sebagai life style saat ini.

Perlu adanya kesadaran untuk dapat memahami setiap arti ibadah sesungguhnya yang semestinya dilakukan dengan keimanan, ketaqwaan dan khusyu' agar sampai kepada tujuan haji yang mabrur. Menata niat dan tujuan kembali sebagai evaluasi diri mulai saat ini dibekali dasar-dasar materi keagamaan yang bersumber jelas terhadap Al-Quran dan Hadist. Yaitu upaya menghadapi perkembangan zaman yang secara sadar ataupun tidak telah mempengaruhi berbagai aspek.

\section{DAFTAR REFERENSI}

Adminsumbar, "Memanggil Dan Menulis Titel H-Hj”. (2013). https://sumbar.kemenag.go.id/v2/post/3313/memanggil-danmenulis-titel-h--hj.html, dikutip Pada 6 Juni 2021

Arif, Firman Muhammad. (2019). "Penyelenggaraan Ibadah Umrah Berbasis Maslahat". Al Amwal. 4(1)

Ali, Aziz Mohammad. (2017). Imu Dakwah. Edisi Revisi. Cet. Ke-6, Jakarta: Kencana

Ali, Syari'ati. (2003). Manusia Menjadi Haji. Yogyakarta: Jalasutra

Estimasi waiting list jamaah Haji. (2019). https:// haji.kemenag.go.id/v4/waiting-list, dikutip pada 6 Juni 2021 Idawati. (2017). "Persoalan-Persoalan Kontemporer Yang Terjadi Dalam Pelalaksanaan Ibadah Haji”. Jumal Warta edisi: 51.

Istianah. (2016). "Prosesi Haji Dan Maknanya". Jurnal : Akblak Dan Tasawnf. 2(1)

Muhammad Munir, I. W. (2006). Manajemen Dakwah. Jakarta: Prenadamedia Group.

Muhammad, Nuri. (2014). "Pragmatisme Penyelenggaraan Ibadah Haji Di Indonesia", Jurnal: Filsafat Dan Budaya Hukum, 1(1)

Nurcholish, Madjid. (1997). Perjalanan Religious Umrab Dan Haji. Jakarta: Paramadina

Purwanto Yedi, T.M \& Jatnika W.A. (2017). "Peran Teknologi Informasi Dalam Perkembangan Dakwah Mahasiswa" Jurnal: Sosioteknologi, Volume 16 (1)

Quraish, Shihab. (2012). "Haji Dan Umrab Bersama M. Quraish Shibab". Tangerang: Lentera Hati. 
Santoso, Bobby Rachman. (2019). "Revitalisasi Metode Dakwah Anakronistis Dai Generasi Milenial." Tasâmub 17.1 133-154.

Sucipto. (2013). Jurnal Komodifikasi Umroh Sebagai Gaya Hidup", Jurnal : Kontekstualita. 28(1)

Zainal. (2012). Regulasi Haji Indonesia Dalam Tinjauan Sejarah. Jurnal : Ilmiah Syariah. 11(2) 